
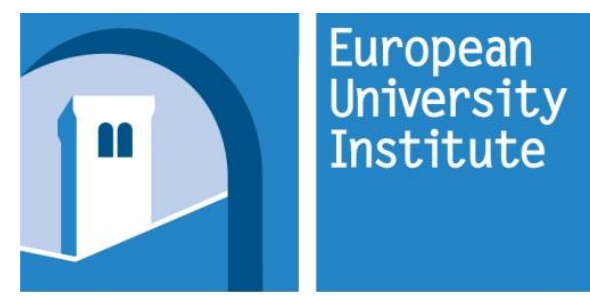

ROBERT

SCHUMAN

CENTRE FOR

ADVANCED

STUDIES

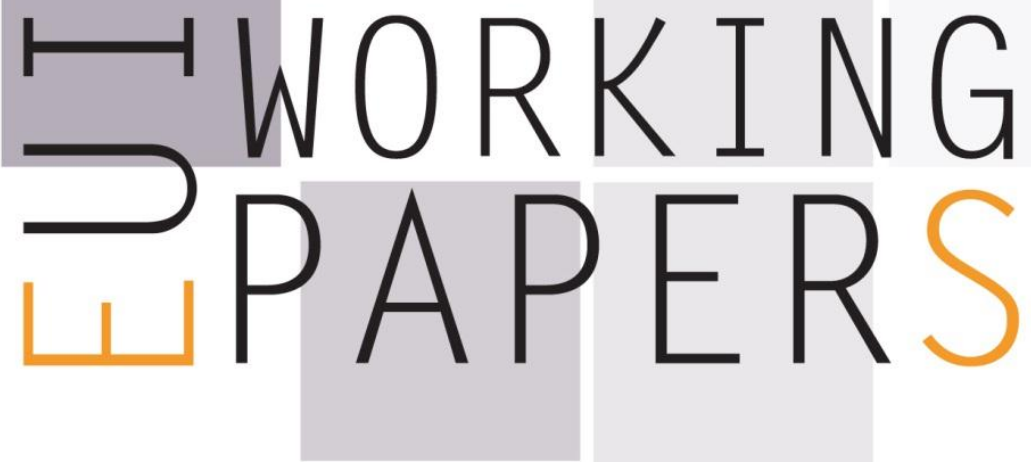

RSCAS 2013/66

Robert Schuman Centre for Advanced Studies

Loyola de Palacio Programme on Energy Policy

The EU Internal Electricity Market: Done Forever?

Jean-Michel Glachant and Sophia Ruester 

European University Institute

Robert Schuman Centre for Advanced Studies

Loyola de Palacio Programme on Energy Policy

\section{The EU Internal Electricity Market: Done Forever?}

Jean-Michel Glachant and Sophia Ruester

EUI Working Paper RSCAS 2013/66 
This text may be downloaded only for personal research purposes. Additional reproduction for other purposes, whether in hard copies or electronically, requires the consent of the author(s), editor(s). If cited or quoted, reference should be made to the full name of the author(s), editor(s), the title, the working paper, or other series, the year and the publisher.

ISSN 1028-3625

(C) Jean-Michel Glachant and Sophia Ruester, 2013

Printed in Italy, September 2013

European University Institute

Badia Fiesolana

I - 50014 San Domenico di Fiesole (FI)

Italy

www.eui.eu/RSCAS/Publications/

www.eui.eu

cadmus.eui.eu 


\section{Robert Schuman Centre for Advanced Studies}

The Robert Schuman Centre for Advanced Studies (RSCAS), created in 1992 and directed by Brigid Laffan since September 2013, aims to develop inter-disciplinary and comparative research and to promote work on the major issues facing the process of integration and European society.

The Centre is home to a large post-doctoral programme and hosts major research programmes and projects, and a range of working groups and ad hoc initiatives. The research agenda is organised around a set of core themes and is continuously evolving, reflecting the changing agenda of European integration and the expanding membership of the European Union.

Details of the research of the Centre can be found on:

http://www.eui.eu/RSCAS/Research/

Research publications take the form of Working Papers, Policy Papers, Distinguished Lectures and books. Most of these are also available on the RSCAS website:

http://www.eui.eu/RSCAS/Publications/

The EUI and the RSCAS are not responsible for the opinion expressed by the author(s).

\section{Loyola de Palacio Energy Policy Chair}

The Loyola de Palacio Energy Policy Chair was created in October 2008 at the RSCAS in honour of Loyola de Palacio, former Vice President of the European Commission and Commissioner for Energy and Transportation in the Prodi Commission. It promotes research in the area of energy policy. It is funded by contributions from donors. Professor Jean-Michel Glachant is the holder of the Chair.

The Chair focuses on the fields of energy economics, law, regulation, as well as geo-politics. It addresses topics such as the achievement of the EU internal energy market; sustainable energy systems and the environment; energy security of supply; the EU model of energy regulation; the EU energy competition policy; the EU policy towards carbon free energy systems in 2050.

The series of working papers aims at disseminating the work of academics on the above-mentioned energy policy issues.

\section{For further information}

Loyola de Palacio Energy Policy Chair

Nicole Ahner (scientific coordinator)

Email contact: Nicole.Ahner@eui.eu

Robert Schuman Centre for Advanced Studies

European University Institute

Via delle Fontanelle, 19

I-50016 San Domenico di Fiesole (FI)

Fax: +390554685755

http://www.loyola-de-palacio-chair.eu 



\begin{abstract}
Taking a quarter-century to build a European internal market for electricity may seem an incredibly long journey. The aim of achieving a European-wide market might be reached, but we have gone through - and should continue to go through - a process subject to many adverse dynamics. The EU internal market may derail greatly in the coming years from the effects of a massive push for renewables, as well as a growing decentralization of the production-consumption loop. Moreover, a serious concern is the risk of a definitive fragmentation of the European electricity market due to uncoordinated national moves with respect to renewable support and capacity mechanisms.
\end{abstract}

\title{
Keywords
}

EU internal market, Power sector reform, Renewable integration 



\section{Introduction}

It took us a while to build an EU internal market for electricity. According to the Single European Act strategy of Commission President Jacques Delors, signed in 1986, it should have been implemented back in ... 1992 - but that turned out to be only the first chapter of a 25-year - still on-going process.

Electricity sector liberalization started in the UK, followed by Norway, from the premise that while networks are natural monopolies requiring regulatory control, generation and trade are potentially competitive activities. The European liberalization process had been set out to simultaneously target two goals, i.e. first, to achieve competitive prices through the play of market forces, and second, to achieve a unified energy market and thus contribute to the "ever closer Union" that also will be conducive to ensuring secure energy supplies.

Much was achieved since the early 1990s. Wholesale and retail markets were liberalized and the eligibility of customers became mandatory with a general increase in the choice of suppliers and tariffs (ACER/CEER, 2012). Even though there are still significant differences between Member States in terms of electricity generation structure, in general, we no longer have a patchwork of closed national energy systems, each with a national-only company controlling the entire electricity sector (EC, 2012). However, certain anti-market arrangements, such as ill-designed regulated end-user prices, still prevail in many countries.

EU officials claim that a first version of this European-wide power market should work by 2015 while we also know that this market is only going to implement the "old" goal of 1996, i.e. of the first EU Internal Electricity Market Directive. ${ }^{1}$ So one might wonder whether this will be the end of the journey, or just a coffee break? This EU's internal electricity market is already seriously challenged by two waves of disruptive innovations - the renewable energy sources and the smartening of the energy system's interactions. It is also challenged by exogenous shocks like the economic and financial crises, the Fukushima accident, or the flooding of cheap gas or cheap coal as a consequence of the US shale gas revolution. Accordingly, the goal of building a cohesive set of market arrangements in the EU cannot stop today or tomorrow and we already know that what we need will be of a different nature than in the 1990s.

This paper argues that existing regulation - once fully implemented - adds up to a "European market", even though many market arrangements differ from the perfect textbook case (Stoft, 2002; Kirschen and Strbac, 2004) (Section 2). However, since the initial power sector reform draft was neither conceived for systems with a massive penetration of renewables, nor for a decentralization of the production-consumption loop, there is, thus, a need to revisit regulatory practice in the whole spectrum of market and network arrangements (Section 3). This obvious need to adapt market design and regulation to "unforeseen" developments, however, is not the only challenge. What is currently becoming a growing concern is the risk of a deep fragmentation of the European electricity market due to uncoordinated national policy initiatives in the areas of renewable support and capacity mechanisms (Section 4).

\section{Europe's single electricity market: Done by 2015 ?}

Taking a quarter-century (from 1990 to 2015) to build Europe's internal market for electricity may seem an incredibly long journey as well as an example of the EU's inability to accomplish serious industry reforms. But we should remember that no other "federal-style" government of a major

1 Directive 96/92/EC 'concerning common rules for the internal market in electricity'. 
country (such as the US, Canada, Brazil, Russia, India or China) has achieved an internal, continentwide, open market for electricity so far.

There are many good reasons for why Europe has been so slow with the liberalization of its electricity sector, as discussed in-depth in Glachant (2013). This market project aimed to open up national monopolies' territories to foreigners, and that of course was a radical project that inevitably triggered huge and fierce opposition. Second, there was no wave of disruptive technological innovation - unlike in the case of telecoms - to challenge the incumbent energy giants. Third, electricity is a difficult product to trade as it requires hundreds of technical, legal and economic rules and standards to be agreed upon before it becomes tradable. Electricity is, after all, not more than a coordinated flow of electrons inside the millions of metallic wires of a gigantic interconnected network. Thus, electricity was considered for decades to be a typical "anti-market" product, best suited to natural or franchised monopolies. In fact, it has been the revolution in the ICT sector that has enabled new market arrangements in the electricity industry. New information and communication technologies gave us the tools to register every move of electricity generators and consumers alike and so permitting one generator and one consumer to trade bilaterally in a market in parallel to the electron flow variations. The fourth reason is that the various national arrangements historically developed between industry players and public authorities cannot easily be merged at the EU level into a common scheme of interoperable markets.

Several successive packages have then been needed to get (near to) all EU countries to implement compatible market arrangements. These include the European Commission's three energy packages (adopted in 1996, 2003 and 2009, respectively) with the third ${ }^{(2)}$ calling for effective unbundling of generation and supply interests from the network and increased transparency of retail markets. Plus the establishment of an Agency for the Cooperation of Energy Regulators (ACER) in order to ensure effective coordination between national regulatory authorities and to take decisions on cross-border issues as well as the establishment of a European Network for Transmission System Operators (ENTSO-E) to push all grid operators to cooperate and to develop common commercial and technical codes or security standards. Moreover, a supplementary Infrastructure Package ${ }^{(3)}$ (adopted in 2013) defines rules to identify "projects of common interest" (PCIs) for infrastructures within a number of key trans-European energy corridors and areas.

If today we ask ourselves whether these existing arrangements - once fully implemented - add up to a "European market", the answer is yes. Whereas in the old times, trade across borders of areas controlled by different transmission system operators (TSOs) was mostly guided by security rather than economic considerations (Newbery, 2009), today we have a set of national, day-ahead wholesale markets that are mostly connected by implicit access given to physical interconnections from the trade floor. Any bid accepted in an exchange is simultaneously taken into account by the other exchanges and by the TSOs that manage the interconnections in between. Whenever there is significant congestion in the network, the European market splits into smaller regional or national markets until the congestion is ended. Secondly, we have more and more intraday and "real-time" arrangements by which offers of capacity and energy services also cross the borders of electrical zones. Third, the network is itself becoming more and more Europeanized. New grid operation codes are being conceived at the EU level, and a common strategic planning of the EU grid is taking place under the "Ten Year Network Development Plans" adopted bi-annually by ENTSO-E. The set of PCIs is also due to adapt our infrastructures better to the internal market's needs.

\footnotetext{
2 Directive 2009/72/EC 'concerning common rules for the internal market in electricity'; Regulation 714/2009 'on conditions for access to the network for cross-border exchanges in electricity'; and Regulation 713/2009 'establishing an Agency for the Cooperation of Energy Regulators'.

3 Regulation $347 / 2013$ 'on guidelines for trans-European energy infrastructure'.
} 
Having said all this, it is nevertheless true that many anti-market arrangements still survive in too many European countries. At the wholesale level, byzantine market arrangements can be considered a "re-regulated access regime", not only in France and Spain, but also in the UK in light of its new nuclear power program (UK Government, 2013). At the retail level, national governments have typically been reluctant to eliminate regulated end-user tariffs (de Suzzoni, 2009; ERGEG, 2010), which, however, discourage consumers from searching for alternative suppliers and, even more consequential, might prevent their exposure to more elaborate price signals. Unfair competition arises if these tariffs are not even aligned with wholesale prices and instead establish values deliberately below the minimum levels needed to cover the cost of energy (plus the regulated charges, which include also network tariffs, subsidies to renewables, taxes, et cetera). It may result in billions of euros of "tariff deficits", as is notably the case in Spain already in the range of $€ 25$ billion (Marañón and Morata, 2011). Moreover, insufficient unbundling of distribution companies can be a serious obstacle to competition (Davies and Waddams Price, 2007; Nikogosian and Veith, 2011, and references therein), given that DSOs should act as "entry gates to retail markets [...] making them an important influence on the level of competition as well" (CEER, 2013).

The degree of market liberalization and competition still varies significantly across the EU and there is consensus on "room for more competition in power markets" (Lowe, 2011). National distortions have significant effects, but they cannot entirely block the internal market from functioning. However imperfect the EU's internal market may be, there can be no doubt that we now are very near to the market target set in 1986.

\section{Europe's single electricity market: But also done forever?}

It is far from guaranteed that this late internal market for energy will work forever. The many national compromises that have been realigned and harmonized in successive EU compromises dealt with the past, and aimed at opening up an EU market as conceived in the 1990s. However, many unforeseen yet dramatic changes have happened during the past 20 years. And these shifts from the initial power reform draft are not at the periphery of the system. They are at its core. We might call them the "major sins" of our EU market and network reform. Their actual number is heavily debated, let us say five to seven.

What we now experience in the EU is not the former "common market - yes; common energy policy - never" which framed the European policy for the twenty years after 1986. We are now under a common energy policy frame designed at the EU level in 2007, when the European Council decided in Berlin to go for it. To this end, a set of Directives was approved in 2009, well-known today as the "20-20-20 climate and energy package". ${ }^{4}$ Parallel to that, a wave of "smart" innovations, such as advanced electricity meters, automation and remote control technologies, et cetera is growing. You might end up with an internal market headache: the energy policy frame did move, and key technologies too are moving.

\subsection{Today's generation mix is split into two opposite sets of generators}

In the early 1990s, we were pretty sure that most of the "steam for markets for power" was there. At that time generation did not seem like any type of natural monopoly except in very rare cases where

4 In order to achieve the "20-20-20 objectives" (i.e. a 20\% reduction in EU greenhouse gas emissions from 1990 levels; raising the share of EU energy consumption produced from renewable resources to 20\%; and the reduction of EU primary energy use by at least $20 \%$ compared with projected levels - all by 2020), this package included a strengthening of existing policy tools as well as the implementation of new instruments. It stands mainly on three pillars: (a) a revision and strengthening of the EU emissions trading system (Directive 2009/29/EC); (b) an Effort Sharing Agreement governing GHG emissions from sectors not covered by the EU ETS (Decision 406/2009/EC); and (c) binding national targets for renewable energy (Directive 2009/28/EC). 
the size of the market is too small to duplicate the existing generation facility (pocket market). Free entry in generation, free choice of the fuel or primary resource, of the technology and the plant size (if not the location) should act to break up the old world of chartered territories for incumbent generation self-planning. This belief is heavily questioned today.

Renewables are pushed in the electricity sector from outside the market. Both wind and solar PV energy run at the speed of their feed-in tariffs, or similar forms of subsidies (see e.g. Held et al., 2010; Marques and Fuinhas, 2012; Ragwitz, 2013). Germany, for instance, is already deploying renewable generation to "a spectacular - and destabilizing - extent" (Buchan, 2013). The country doubled its renewable generation capacity, which increased from less than $40 \mathrm{GW}$ in 2008 to more than $80 \mathrm{GW}$ today. With virtually no barriers for entering the electrical system, renewables enjoy considerable advantages: they always have guaranteed access to existing consumption, whereas conventional thermal generation only has access to the residual demand. In some EU countries, renewables also have the right to connect to the grid, and the grid owner has a duty to invest accordingly (Ecofys et al., 2011).

Step by step, a significant proportion of Europe's thermal power plants are selling less and less energy while providing more and more "flexible capacity" for the electrical system. Some countries like the UK and France are looking at bridging that power generation revenue gap by re-organizing their national market's capacity arrangements. Obviously enough, this might well break up the EU's internal market, as some thermal generators would still be paid only for the energy they can sell, while others would get both those energy revenues and a national capacity payment.

Even if there were to be no capacity splitting of the market, the present wholesale market might well undergo profound changes under the pressure of the growing share occupied by renewables. Large amounts of energy generated by renewables entering the wholesale market greatly depress the market price. The variable cost of generating electricity with renewables is low, and a competitive energy market uses the variable cost of marginal power generation to price the market as a whole. That price can then easily drop close to zero if the market is flooded by renewable energy. It can even fall below zero into negative prices, as is regularly observable within e.g. the German market area (EEX, 2013). Some thermal generators in such situations prefer to pay for the right to keep their plants running, as thermal plants may face difficulties when reducing their output (they have to contend with huge output start-up costs and other dynamics).

But in depressed conditions of this sort, how could the wholesale day-ahead market, that is the strongest backbone of the EU internal market, maintain its central position in the chain of electricity market arrangements that stretches from futures to real-time? The renewables push through feed-in tariffs largely locates the generation structure change in the realm of a public authority. The renewable priority of dispatch both reduces the market size remaining for non-renewable generators and breaks the price trend at which they can make money or break even. Hence, the generation set is deeply fractured into two opposite sets of generators: on the one hand "new" generators bearing no significant risk for capacity, volume or price thanks to e.g. feed-in tariffs/premiums and priority dispatch, and on the other hand the "conventional" generators bearing a significantly increased uncertainty, and foreseeably depressed future.

\subsection{Technological shocks can have unpredictable impacts on the available set of and relative cost of generation technologies}

The current EU Energy Roadmap scenarios (EC, 2011) build on a menu of essentially known technologies. They also have been criticized as relying on outdated cost assumptions for different lowcarbon technologies (Hirschhausen et al., 2013). For sure, 2050 is 37 years from now and thinking 40 years ago, there had not been the oil crises yet. European energy markets had only national structures and electricity generation from renewable sources only included some hydro power. In 2050, the energy system will probably be extremely different than it is today. Composing an adequate portfolio 
of generation technologies has a very long time horizon; it is not only about looking ahead to the 2050 decarbonization target, but to technological lock-ins that might persist even beyond (Ruester et al., 2013d).

On the one hand, some unforeseen technological shocks can eliminate technology options. For instance, a "2050 bridging role" was given to nuclear in the first version of the German energy strategy in late 2010, whereas one year later the country announced a nuclear phase out by 2022 as a response to the Fukushima accident.

On the other hand, unforeseen technological revolutions can also add new or cheaper means of generation and decarbonization. For instance, whereas the International Energy Agency in its World Energy Outlook 2007 (at the time when the 20-20-20 strategy was adopted by the European Council) predicted a moderate growth for US gas production. Four years later, the World Energy Outlook 2011 was centered around a possible "golden age of gas". Assuming that the US will become a large-scale exporter of cheap gas and that it is possible to replicate its experience in other parts of the world (from the UK to Poland or Ukraine; from India to China), the availability of cheap gas in the market would allow for a degree of decarbonization at low cost (or even net benefits: one should decarbonize to make more money in the market). The 'rational' price of carbon might then fall extremely low under the push of shale gas as a market-based decarbonization technology. Hence, cheap gas may not only substitute dirty coal but also expensive renewables.

Certainly, technological developments, shocks and revolutions can have important, unpredictable impacts on the available set of and relative cost of generation technologies ${ }^{5}$. How can we stimulate sufficient innovation in low-carbon technologies in case of a degree of decarbonization at very low cost and the resulting lack of a strong carbon price signal? How will this interact with the market and network arrangements that we use in the EU as our common market model or network operation frame?

\subsection{Transition from 'top-down' towards 'distributed local' electricity systems}

We observe changes in the generation mix not only in the form of a shift from conventional fossil fuels towards renewables, but also in the form of a shift from centralized towards decentralized resources. More mature technologies for local renewable generation, decreased investment costs thereof and ambitious national support schemes led to a significant market penetration of distributed generation (DG) in many EU countries, and an important share of renewable energy is not fed anymore into the transmission grid but at distribution grid level. In Germany, for instance, "in many places, the DG output of distribution networks already exceeds local load, sometimes by multiple times," see Eurelectric (2013).

Distributed storage might also become viable soon at all voltage levels and in significant amounts, becoming a critical component of the grid of the future (Beaudin et al., 2010; Ruester et al., 2013b). Likewise, the use of electric vehicles charging from local grids, and possibly also the ability to inject power back to it is expected to grow (see e.g. Kampman et al., 2011; Pasaoglu et al., 2012). In addition, recent innovations in metering and communication devices enable active demand response and enhanced distribution automation. Whereas at the beginning of the liberalization process, demand response has been considered only interesting for large, typically industrial, customers (S. Littlechild is one of the very few having always advocated for retail competition and demand response), technological advances today make this concept appealing also for residential consumers (see e.g.

5 Possible technology paths towards a 2050 (decarbonized) electricity system are outlined also e.g. in ECF (2010), Greenpeace (2010), Eurelectric (2011), and IEA (2012). 
Olmos et al., 2011; He et al., 2013; and references therein). ${ }^{6}$ Thanks to solar PV panels, millions of these smart consumers are already or might soon also be producers of electricity. This is famously turning these consumers into "prosumers" and it may therefore have a significant impact on both the offer and demand sides of these fast changing segments of energy markets.

This newly emerging broad range of "distributed energy resources (DER)" (Ruester et al., 2013c) be it distributed generation, local storage, electric vehicles or demand response -also has the potential to drive significant changes in the planning and operation of the power systems. Traditional power systems had been designed to send electricity top-down from generation connected to the transmission level to end consumers connected at distribution grids. And the distribution grid had been designed accordingly such that there were no significant bottlenecks or congestion. In contrast, today's distribution systems are challenged by new features such as increased volatility of net demand and peak demand fluctuations, reverse flows from the distribution to the transmission grid in times of local generation exceeding local demand. It also increases the feasibility and the likelihood of having energy and power trades at the local level, "du jamais vu"!

All these changes bring challenges for electricity distribution system operators (DSOs) and their regulation alike, ranging from increasing uncertainty in distribution grid flows to the necessary integration of new DER business models into retail markets. As we can already see that the distribution grids might become the new core of the EU internal market, the key question we should ask, from a market policy point of view, is how will they operate and how will they be regulated and monitored? Should we avoid a situation in which several thousand DSOs throughout Europe fragment at national and sub-national level the existing EU internal market by spontaneously diverging through myriad of different rules and arrangements? Nobody yet knows how the corresponding new services, whether communication-related or energy-related, and new markets that are immediately responsive to retail demand, will evolve.

\subsection{Network neutrality}

Considering network neutrality as another important sin ("unforeseen" shift) from the initial power reform draft may be controversial while it should not because it actually is a major departure. As a natural monopoly, networks had to be detached from market operation, neutral vis-à-vis fuel mix and cost-based for hosting generation capacity. The main positive outcome that we expected from the networks in the liberalization process was to reduce their costs to their bones, à la RPI-X formula (Ofgem, 2009; Eurelectric, 2010). Transmission as well as distribution grids, however, are now seen as the vanguard of a significant shift of the whole industry to new business models.

\section{Transmission grid and TSO regulation:}

Challenges accompanying the connection and integration of large-scale renewable energy sources are manifold. First, we observe an increasingly unbalanced regional distribution of supply and demand and therefore the transmission grid needs to be reinforced - inside countries but also via extended interconnection capacities - to be able to transport electricity from its sources to its sinks. Second, we expect an increasing share of remote generation, outside the today's European core grid, and new lines need to be built to connect e.g. offshore wind parks, or one day solar power plants in Northern Africa. Furthermore, the economic features of these new resources may presumably be different (different timing of investment and construction; and technically: different load following, production ramping and dispatch firmness profiles). The proper development and operation of networks, far from staying neutral, will strongly interact with the new services, the new users and the new usages of transmission services.

6 Given a positive cost-benefit analysis, at least $80 \%$ of European households are supposed to be equipped with intelligent metering systems by 2020 (EC, 2009). 
For the coming three decades, the Commission estimates that investments in transmission network infrastructures in the range of $€ 100-200$ billion are to be realized (EC, 2011b). The Infrastructure Package could help to identify priority projects; a methodology for cost-benefit analyses is currently developed in order to facilitate the selection of such PCIs (see also Meeus et al., 2013). Nevertheless, serious challenges for investors, grid operators and regulators remain. How to mobilize the required funding, given that under current evolution of transmission tariffs, only half of planned investment could be financed (Henriot, 2013)? How to allocate grid costs, considering that the way we designed grid tariffs for our yesterday's priorities cannot stand forever and that instead new grid tariffs have to be aligned with the new system needs (see e.g. Olmos and Pérez-Arriaga, 2009; Ruester et al., 2012)? ${ }^{7}$

\section{Distribution grid and DSO regulation:}

For high amounts of distributed energy resources (DER), the total costs of business-as-usual management of distribution networks will likely increase in most systems. Substantial future investments are also required to properly connect all these new DER to the distribution networks, to enable the system to deal with increased volatility of net demand and peak demand fluctuations, and to set up an ICT infrastructure that empowers DSOs to employ DER for their daily grid operations. DER offer a new set of instruments for grid operation and thereby a tool for DSOs to perform their tasks of electricity distribution. DER also allow for an active distribution system management and have the potential to decrease the total costs of DSOs compared to not relying on these new resources in local system management, see Cossent (2010), Pieltan-Fernandez et al. (2011), and Yap (2012).

As discussed in-depth in Ruester et al. (2013b), the use of DER in distribution grid management can decrease OPEX compared to a business-as-usual treatment of these resources. In contrast, how the use of DER will impact CAPEX is not obvious. Integrating DER in grid operation procedures can decrease CAPEX in the longer-run if grid investments can be deferred, for instance, relying on DER to solve local congestion can postpone investments in new lines (CAPEX hence being substituted for OPEX). On the other hand, in the short-run, significant expenditures for investments into grids and ICT infrastructures supporting grid monitoring and automation are needed upfront. A challenging task for regulators, therefore, remains to design sound regulation that efficiently incentivizes DSOs to engage in active system management and, thus takes account of the changing OPEX and CAPEX structures and of trade-offs among both (Cossent, 2013).

To end, grid operators are much more than "simple regulated infrastructure monopolies" (like bridge or road) where it might suffice that regulation primarily aims to decrease their costs. Instead, grid operators are becoming important market facilitators who shall favor all welfare-enhancing business models under any future market development. Both transmission and distribution grids are supposed to become smarter platforms for deeper market interactions. Regulators realize that there is more to competition than setting price equal to cost (Littlechild, 2012; Khalfallah and Glachant, 2012). In this vein, grids may be remunerated for hosting more of the "socially preferred" generation mix or even to start innovating and running pilots or demonstrations (e.g. offshore grids). At the end of the day, average grid costs will go up with increased investment costs. The low cost, market distant and energy mix neutral grid revolution may fade away.

\subsection{Market integrity}

A highly concentrated industry structure is detrimental to the development of a functioning and efficient internal energy market. Our initial wisdom was that a "good enough" generation structure is a necessary pre-condition to market opening: why bother opening markets which are structurally unable

7 An interesting proposal is the German "Bürgerdividende". Citizens directly affected by the expansion of the electricity grid shall get the opportunity to take a stake in these new assets with a guaranteed return on investment of up to $5 \%$. See http://www.bundesregierung.de/Content/DE/Artikel/2013/07/2013-07-05-buergerdividende-zum-netzausbau.html 
to be competitive? This was a key question in the UK in 1990 as it is in France today. Illiquid wholesale markets exposed to dominant market players, might not only have negative consequences in terms of potential market power abuse (see e.g. Green, 2006; Weigt and Hirschhausen, 2008), but might also delay the transformation of balancing mechanisms into integrated balancing markets or the development of further interconnection.

Improving the industry structure, however, has been and still is one of the main difficulties in the construction of the internal energy market as Member States are sovereign in defining their industrial structures (Glachant and Lévêque, 2009). The Commission has no right to intervene except in cases of major mergers and acquisitions.

Competition has to be "at least workable", (Bergman, 2009). The consensus was a magic number of five or more competitors, none with more than a $20 \%$ market share. The Californian crisis with FERC blindly sticking to its Herfindahl-Hirschman concentration index prejudice opened many eyes to other unacceptable deficiencies. Wolak (2003) showed that more accurate definitions of market power and more sophisticated econometrics might be able to identify most of the "new industrial economics" way in which market power is abused in power markets.

However, many other doors remained open between market and manipulation. How are thieves or criminals like Enron and others in the financial markets (maybe Barclays or JP Morgan in the US) to be dealt with and how are they to be deterred from destroying the market from inside? If we cannot guarantee ex-ante transparency and integrity in power markets, how can we rely on these markets to bridge physically (unit commitment, dispatch, capacity allocation and congestion management) and financially (price arbitrage, portfolio and risk management, et cetera)? Today we still know more about the "fire alarm" strategy of monitoring (how to assess ex-post the fairness of actual behaviors on existing markets) and less on the "police patrol" strategy (how to ex-ante prevent manipulations or crimes). An obvious link between ex-ante and ex-post strategies is how we conceive the definition and the collection of data, the architecture and languages of data bases and the screening tools, the market models and the software. Moreover, we know more about "country market" monitoring but did we achieve enough across borders and across markets? Finally, another key issue is how to manage the loop between market monitoring, market investigation and market fixing.

\subsection{Market Design}

Market players cannot entirely design power markets by themselves because power markets are structurally incomplete (Smeers, 2003a; 2003b). We saw that market players can easily trade energy until the "market gate closure", but they cannot easily trade the corresponding transmission capacity and reserve availability needed to implement this "ex-ante" energy trade. To alleviate these market difficulties, power markets play the wholesale trade through a series of steps, which mimic the simple offer and demand arrangement of a textbook market. Power markets are actually "sequences of markets" from the pre-commitment of plants at day(s) ahead to the real-time balancing of actual injections and withdrawals, via the allocation of transmission capacity and the necessary management of unforeseen congestions.

Making electricity marketable actually means to complete the textbook market with more central coordination, more third party intervention and market intermediation. If one wants to make electricity a homogenous good easier to contract and to trade, one has to deal with the growing gap between the actual physical flows and the notional traded good. The very nature and the right amount of "third party" coordination in power markets are still under discussion after twenty years. We not only

8 In this vein, the author refers to a market that is "perhaps less perfect than the textbook vision of a competitive market but yet generally free from monopolistic pricing and various forms of collusion and manipulation." 
disagree on how to design complements or auxiliaries to the market but we also disagree on what to keep free for trade.

We did not really foresee how deeply market trade and market interactions will depend on the market arrangements agreed by policy makers here and there. Even if we bypass more than a decade of wholesale storyboard (see also e.g. Boisseleau, 2004; Zachmann, 2008; Glachant, 2010) - UK Pool and New Trading Arrangement, Nord Pool, Germany's dual competing power exchanges, et cetera today we are still discovering how to connect the existing market areas across the existing electrical control zones. Should we "couple" the existing markets within a harmonized nodal frame? Or only with an explicit... or implicit... transmission capacity auctioning? Only on the day-ahead horizon? Should then it be "flow-based" or with rigid predetermined "net transfer capacity"? Should we also couple for intraday trade? With a few successive windows of price fixing? Or with continuous trading? Should we extend to pooling adjacent markets on their balancing horizon? Through a "loose" common pool of offers where several system operators may pick up for their needs? Or through a "tight" cross-border common management of all balancing options? Why not then a loose system operator auxiliary (like CORESO) or a more substantial EU light ISO?

\section{Conclusion: Towards a (re-) fragmentation of the European electricity market?}

Building a European internal market for electricity has been a slow process of some 25 years, but it is soon to be achieved. We Europeans conceived our internal market arrangements "our way", even though many other ways were, or still are, envisageable. Europe could, for example, have opened up the wholesale market without opening the retail market. Or it could have made opening the wholesale market mandatory with a centralized exchange system operating a single price algorithm, just as England did for more than 10 years.

In the end, it has been - and should continue to be - a process subject to lots of dynamics. What we now call the EU internal market is in many elements a compromise among all the other national-level compromises. It is so far from being a perfect mechanism capable of serving us for everything, whatever the prevailing conditions. This emerging EU market may suffer greatly in the coming years from a massive increase in renewable energies or from a deep decentralization of the productionconsumption loop. The future, as is already debated a post-2020 strategy, is far from clear. What is clear, though, is that the introduction of new ICT-based technologies could radically modify the economical and physical functioning of the electricity system and as a result the functioning of the market. Therefore, what is urgently needed now is "a realistic design for the transition process from today's low-ICT, high-carbon energy systems to a high-ICT, low-carbon system of tomorrow" (Vasconcelos, 2013).

The need to adapt market design and network regulation to "unforeseen" developments is not the only challenge. What is currently becoming a serious concern is the risk of a re-fragmentation of the European electricity market due to uncoordinated national moves. It is true that national diversity has first and foremost been a predictable result of the nature of the compromises made when scoping the first electricity directive. The $2^{\text {nd }}$ and $3^{\text {rd }}$ Packages successfully managed to reduce the scope of this diversity. However, we observe now an again increasing impact of national initiatives. Diverse renewable support schemes resulted in a patchwork of effective, but market-distorting subsidies (see e.g. Ragwitz, 2013; CEER, 2013b). Moreover, a number of Member States consider introducing various forms of capacity mechanisms. In Germany, for instance, it targets the high share of intermittent generation blowing conventional generation out of the market and therefore out of money; whereas in the UK it reacts to a shortage in overall capacity due to the shutdown of several dirty power plants.

We know that the Commission will use its powers for policing state aids and, for instance, approve national capacity mechanisms only if the respective Member State devotes funds to improve its 
interconnections with neighbors (Buchan, 2013). It does not tell if European Competition Policy will be the tool able to heal the many wounds of EU market arrangements. Our electricity markets and networks are at the gate of a sea of perils. There is no guarantee that they will sail till the next safe harbor.

\section{References}

ACER/CEER (2012): Annual report on the results of monitoring the internal electricity and natural gas markets in 2011. Report published on 29 November 2012.

Beaudin, M., H. Zareipour, A. Schellenberglabe and W. Rosehart (2010): Energy storage for mitigating the variability of renewable electricity sources: An updated review. Energy for Sustainable Development, 14(4): 302-14.

Bergman, L. (2009): Addressing market power and industry restructuring. In: Glachant and Lévêque (eds.): "Electricity reform in Europe", Edward Elgar.

Boisseleau, F. (2004): The role of power exchanges for the creation of a single European electricity market: Market design and market regulation. Delft University Press.

Buchan, D. (2013): Europe's unresolved energy versus climate policy dilemma. In: "EU's internal energy market: Tough decisions and a daunting agenda", Friends of Europe Discussion Paper.

CEER (2013): Status review on the transposition of unbundling requirements for DSOs and closed distribution system operators. C12-UR-47-03.

CEER (2013b): Status review of renewable and energy efficiency support schemes in Europe. C12SDE-33-03.

Cossent, R. (2013): Economic regulation of DSOs and its adaptation to the penetration of distributed energy resources and smart grid technologies. PhD Thesis, Comillas University Madrid.

Davies, S. and C. Waddams Price (2007): Does ownership unbundling matter? Evidence from UK energy markets. Intereconomics - Review of European Economic Policy 42(6): 297-301.

de Suzzoni, P. (2009): Are regulated prices against the market? European Review of Energy Markets, 3(3): $1-30$.

EC (2009): Directive 2009/72/EC concerning common rules for the internal market in electricity.

EC (2011): A roadmap for moving to a competitive low-carbon economy in 2050. COM(2011) 112.

EC (2011b): Smart electricity grids. SETIS Technology Information Sheet. http://setis.ec.europa.eu/system/files/Smartgrid.pdf

EC (2012): Energy markets in the European Union in 2011 (Chapter 2.3). SWD(2012) 368.

ECF (European Climate Foundation) and McKinsey (2010): A Practical Guide to a Prosperous Low Carbon Europe.

Ecofys, Fraunhofer ISI, EEG and LEI (2011): Renewable energy policy country profiles. Report prepared within the Intelligent Energy Europe project RE-Shaping - Shaping an effective and efficient European renewable energy market.

EEX (2013): European Energy Exchange (EEX) - power trading data http://www.eex.com/en/Market\%20Data/Trading\%20Data/Power

ERGEG (2010): Status review of end-user price regulation as of 1 January 2010. E10-CEM-34-03.

Eurelectric (2011): Power Choices - Pathways to carbon-neutral electricity in Europe by 2050. 
Eurelectric (2013): Active Distribution System Management - A key tool for the smooth integration of distributed generation. Discussion Paper.

Glachant, J.-M. (2010): The achievement of the EU electricity internal market through market coupling. European University Institute, EUI Working Paper RSCAS 2010/87.

Glachant, J.-M. (2013): The Three Ages of Europe's Single Electricity Market. In: "EU's internal energy market: Tough decisions and a daunting agenda", Friends of Europe Discussion Paper.

Glachant, J.-M. and F. Lévêque (2009): The electricity internal market in the European Union: What to do next? In: Glachant and Lévêque (eds.): "Electricity reform in Europe", Edward Elgar.

Green, R. (2006): Market power mitigation in the UK power market. Utilities Policy, 14(2): 76-89.

Greenpeace (2010): Energy (R)evolution - Towards a fully renewable energy supply in the EU-27.

He, X., L. Hancher, I. Azevedo, N. Keyaerts, L. Meeus and J.-M. Glachant (2013): Shift, not drift: Towards active demand response and beyond. THINK report. Available at http://www.think.eui.eu

Held, A., M. Ragwitz, M. Rathmann and C. Klessmann (2010): RE-Shaping: Shaping an effective and efficient European renewable energy market. Indicators assessing the performance of renewable energy support policies in 27 Member States. EIE/08/517/SI2.529243. Fraunhofer ISI, Karlsruhe.

Henriot, A. (2013): Financing Investment in the European Electricity Transmission Network: Consequences on Long-Term Sustainability of the TSOs Financial Structure. European University Institute, EUI Working Paper RSCAS 2013/27.

Hirschhausen, C.v., C. Kemfert, F. Kunz and R. Mendelevitch (2013): Europäische Stromerzeugung nach 2020: Beitrag erneuerbarer Energien nicht unterschätzen. German Institute for Economic Research, DIW Wochenbericht 29/2013.

International Energy Agency (2012): Energy Technology Perspectives 2012 - Pathways to a clean energy system.

Kampman, B., H. van Essen, W. Braat, M. Grünig, R. Kantamaneni, and E. Gabel (2011): Impact analysis for market uptake scenarios and policy implications. Report by CE Delft, ICF International and Ecologic.

Khalfallah, H. and J.-M. Glachant (2012): An assessment of the tools of incentive regulation in electricity networks. Economics and Policy of Energy and the Environment, 51(1): 121-52.

Kirschen, D.S. and G. Strbac (2004): Fundamentals of power system economics. John Wiley \& Sons Ltd.

Littlechild, S. (2012): Regulation and customer engagement. Economics of Energy \& Environmental Policy, 1(1): 53-68.

Lowe, P. (2011): Getting to 2014 - The completion of the EU internal energy market. Presentation available at http://webcast.ec.europa.eu/eutv/portal/archive.html?viewConference=12953

Marañón, M. and A. Morata (2011): Tariff deficit in retail electricity markets in Spain. Network Industries Quarterly, 13(1): 23-6.

Marques, A.C. and J.A. Fuinhas (2012): Are public policies towards renewables successful? Evidence from European countries. Renewable Energy, 44(August): 109-18.

Meeus, L., N.-H. von der Fehr, I. Azevedo, X. He, L. Olmos and J.-M. Glachant (2013): Cost benefit analysis in the context of the energy infrastructure package. THINK report. Available at http://www.think.eui.eu

Newbery, D. (2009): Refining market design. In: Glachant and Lévêque (eds.): "Electricity reform in Europe", Edward Elgar. 
Nikogosian, V. and T. Veith (2011): Vertical Integration, Separation and Non-Price Discrimination: An Empirical Analysis of German Electricity Markets for Residential Customers, ZEW Discussion Paper No. 11-069.

Ofgem (2009): Regulating energy networks for the future: RPI-X@20 - History of energy network regulation. Ofgem Supporting Paper, 13b/09.

Olmos, L. and I.J. Pérez-Arriaga (2009): A comprehensive approach for computation and implementation of efficient electricity transmission network charges. Energy Policy 37(23): 528595.

Olmos, L., S. Ruester, S.-J. Liong and J.-M. Glachant (2011): Energy efficiency actions related to the rollout of smart meters for small consumers - Application to the Austrian system. Energy, 36(7): 4396-409.

Pasaoglu, G., M. Honselaar and C. Thiel (2012): Potential vehicle fleet CO2 reductions and cost implications for various vehicle technology deployment scenarios in Europe. Energy Policy, 40(1): 40421.

Ragwitz, M. (2013): EU renewable energy support schemes - Status quo and need for reform. Presentation at the 'Workshop in Preparation of the Review of EU Guidelines on State Aid for Environmental Protection', Brussels, 04 April 2013.

Ruester, S., X. He and J. Vasconcelos (2013b): Electricity storage: Need for a particular EU policy to facilitate its deployment and operation? European Energy Journal, 3(2): 23-31.

Ruester, S., S. Schwenen, I. Pérez-Arriaga, C. Batlle and J.-M. Glachant (2013c): From Distribution Networks to Smart Distribution Systems: Rethinking the Regulation of European Electricity DSOs. THINK report. Available at http://www.think.eui.eu

Ruester, S., S. Schwenen, M. Finger and J.-M. Glachant (2013d): A strategic energy technology policy towards 2050: No-regret strategies for European technology push. European University Institute, EUI Working Paper RSCAS 2013/40.

Stoft, S. (2002): Power system economics - Designing markets for electricity. IEEE Press \& WileyInterscience.

Smeers, Y. (2003a): Market incompleteness in regional electricity transmission. Part I: The forward market. Networks and Spatial Economics, 3(2): 151-74.

Smeers, Y. (2003b): Market incompleteness in regional electricity transmission. Part II: The forward and real-time markets. Networks and Spatial Economics, 3(2): 175-96.

UK Government (2013): Community benefits for sites that host new nuclear power stations. Written statement to Parliament by the UK Energy Minister Michael Fallon. https://www.gov.uk/government/speeches/community-benefits-for-sites-that-host-new-nuclearpower-stations-michael-fallon

Vasconcelos, J. (2013): 'The stuff we have, a strong wind will blow it to pieces': Two decades behind schedule, we need to re-think the single electricity market. In: "EU's internal energy market: Tough decisions and a daunting agenda", Friends of Europe Discussion Paper.

Weigt, H. and C.v. Hirschhausen (2008): Price formation and market power in the German wholesale electricity market. Energy Policy, 36(11): 4227-34.

Wolak, F.A. (2003): Measuring unilateral market power in wholesale electricity markets: The California market, 1998-2000. American Economic Review, 93(2): 425-30.

Zachmann, G. (2008): Electricity wholesale market prices in Europe: Convergence? Energy Economics, 30(4): 1659-71. 
Authors contacts:

\section{Jean-Michel Glachant (Corresponding author)}

Director of the Florence School of Regulation and holder of the "Loyola de Palacio" Chair

RSCAS, European University Institute

Villa Malafrasca, Via Boccaccio, 151

50133 Firenze

Italy

Email: jean-michel.glachant@eui.eu

\section{Sophia Ruester}

Florence School of Regulation

RSCAS, European University Institute

Villa Malafrasca, Via Boccaccio, 151

50133 Firenze

Italy

Email: sophia.ruester@eui.eu 